\title{
The Ethics of Pre-implantation Genetic Diagnosis: An Opinion Piece Examining the Moral Distinction Between Positive and Negative Selection of Traits Using PGD
}

Helena BLEEKER* 1

1 Student, University of Ottawa, Canada

*Auteur(e) correspondant | Corresponding author: eleni.bleeker@gmail.com

Résumé :

(traduction)

Mots-clés :
Abstract:

Le diagnostic préimplantatoire (DPI) suit la fécondation in vitro (FIV) de plusieurs ovules. Dans ce cadre, la sélection négative (SN), ou le rejet d'embryons contenant des allèles indésirables, est actuellement une pratique courante dans les cliniques de FIV. La sélection positive (SP), quant à elle, est le rejet d'embryons qui ne contiennent pas un allèle désirable - en d'autres termes, la SP conserve un embryon car il renferme un profil génétique souhaitable.

De nombreux groupes sont en faveur de la SN, mais il y a beaucoup moins de partisans de la SP. La philosophie bio-conservatrice, dirigée par des philosophes tels que Leon Kass, s'oppose à la SP et au bio-libéralisme en général. À l'inverse, la SN (et SP) d'embryons résonne mieux avec la philosophie bio-libérale, plus précisément avec un sous-ensemble du bio-libéralisme appelé le «transhumanisme ».

Pour pouvoir considérer que la SN est moralement admissible et que la SP est moralement inacceptable, il faut soutenir sa position en faisant une distinction entre les deux types de sélection. Les réclamations majeures contre la SP comprennent le fait que ce n'est pas médicalement grave, qu'elle répand l'eugénisme, qu'elle propage la sélection du sexe et qu'elle suscite une aversion morale qui prouve son immoralité. Dans l'analyse de ces arguments, j'espère démontrer qu'aucun d'entre eux n'est cohérent dans leur application, et que leur incapacité à être appliqués de manière universelle mine leur propre cause.

N/A

Pre-implantation genetic diagnosis (PGD) follows in vitro fertilization (IVF) of several ova. Negative selection (NS), or the discarding of embryos containing undesirable alleles, is currently being performed in IVF clinics. Conversely, positive selection (PS) is the discarding of embryos that do not contain a desirable allele. In other words, PS keeps an embryo because it contains a desirable genetic profile.

There are many groups that support NS but there are far fewer who support PS. The bioconservative philosophy, led by philosophers such as Leon Kass, opposes PS and bioliberalism in general. Conversely, NS (and PS) of embryos resonates best of all with the bioliberalism philosophy. More specifically, a subset of bioliberalism, called transhumanism.

In order to find NS morally permissible and PS morally unacceptable, one must support one's position by making a moral distinction between the two types of selection. 
The major claims against PS include that it is not medically serious, that it propagates eugenics, that it propagates sex selection and that it elicits a moral repugnance which proves its immorality. In analyzing these arguments, I hope to show that none of them are consistent in their application, and that their inability to be applied universally significantly weakens their case.

Keywords:

N/A 


\section{Introduction to Pre-implantation Genetic Di- agnosis and its Uses}

Pre-implantation genetic diagnosis (PGD) follows in vitro fertilization (IVF) of several ova ${ }^{1}$. Negative selection (NS), or the discarding of embryos containing undesirable alleles ${ }^{2}$, is currently being performed in IVF clinics (Purdy, 1996). Conversely, positive selection (PS) is the act of selecting embryos because they do contain desirable alleles. In other words, PS keeps an embryo because it contains a desirable genetic profile3.

I will begin by presenting a summary of the support for NS, which is widely accepted for diseases such as Huntington's (Abraham, 2012; Glover, 1984). As far as severely painful diseases go, or those that give the infant a very low life expectancy, NS is an attractive technology, even surviving the abortion debate as some anti-abortionists condone its use ${ }^{4}$. NS of embryos is also attractive to supporters of Judith Jarvis Thomson's autonomy-based philosophy5

(Thompson, 1971). If this is true, NS simply allows parents to exercise their autonomy if they decide that they are not prepared to raise a child with a debilitating or life threatening genetic condition. Utilitarian philosophers such as Peter Singer would offer a third rationale for supporting NS of embryos ${ }^{6}$ (Singer, 1974). In that light, it may be beneficial to the world as a whole (or the sum of the world's persons) to refrain from bringing more children into the world who will live in pain and/or psychological distress (Purdy, 1996), who will require very costly treatments that put a strain on the health care system, and who will have lower utility in society. It is likely that the NS (and PS) of embryos resonates best of all with the bioliberalism philosophy; more specifically, a subset of bioliberalism, called transhumanism7. Transhumanists argue that genetic selection of embryos could benefit the future individual by improving physical wellbeing, intelligence, emotional stability and resiliency to stressors. To a transhumanist, the failure to use such technologies would be a failure to move humanity forward (Roache \& Clarke, 2009).

Overall, the numerous philosophies that permit the NS of embryos containing several disease genes seem to be supported and put to practice by Canadian society 8 (Abraham, 2012). Of course, it does not follow that widespread desire for PS will necessarily drive its global acceptance9 (Abraham, 2012). The bioconservative philosophy, led by philosophers such as Leon Kass, opposes PS and bioliberalism in general. There is also continual opposition against all forms of PGD - and IVF in general - from those who believe that embryos have a right to life ${ }^{10}$. I will not get into that particular debate in this essay. As we will see, there are many lines of opposition to PS from outside the anti-abortionist philosophy. My interest here is the distinctive line that may or may not be drawn between different forms of embryo selection using PGD (which IVF). For ease of discussion, it will be assumed that embryos are not persons and have no right to life.

From here, I would like to address the following questions within the context of PGD. There are many groups that support NS, but far fewer who support PS as well (Roache \& Clarke, 2009; Bostrom \& Savulescu, 2008). In order to find NS morally permissible and PS morally unacceptable, one must support one's position by making a moral distinction between the two types of selection. I will make the claim that the majority of such arguments are weak, and do not make a satisfactory case against PS. If there is no satisfactory argument to morally differentiate NS from PS, I would argue that in accepting the former, we must also accept the latter. To begin, I would like to address several arguments made against PS by supporters of NS. In order to hold PS impermissible while NS permissible, they must create a morally relevant distinction between PS and NS. Either PS must possess some morally relevant element that NS does not, or vice versa. In analyzing these arguments, I hope to show that none of them are consistent in their application to real-life situations, and that their inability to be applied universally significantly weakens their case.

\section{Argument 1 - NS is always to avoid medically serious traits, while PS focuses on genes for trivial traits:}

The 'medical seriousness' argument refers to the application of NS only to embryos containing a dangerous, debilitating, or pain-causing gene. The problem with PS is that its focus is on genes for traits that are not medically serious or dangerous (Glover, 1984). This results in the creation 'designer babies' because there is picking and choosing of non-critical, also called 'trivial' traits. Proponents of this claim are religious bodies, geneticists, and physicians who believe that removing life-threatening genes is the moral limit for PGD application (Abraham, 2012).

This claim is too narrow. There are as many trivial or designer traits that could undergo NS as there are those that are medically serious. If the presence of a gene coding for 
shortness, dark hair, brown eyes or creative intelligence (versus mathematics/logical intelligence) causes an embryo to be discarded, then this is no doubt an example of NS being used for 'trivial' traits. Consider some less extreme trait examples that are already undergoing NS in some fertility clinics. Genes for psoriasis, albinism, cleft palate, none of which are life threatening, are some examples of genes that undergo NS by parents (Abraham, 2012). Although perhaps less trivial than height, can these traits be considered medically serious? Moreover, there may be 'serious' traits that, upon closer consideration, actually require PS. Consider a rare gene allele that makes one immune to an infectious disease: malaria, tuberculosis or influenza. Would PS of such a trait not be on equally medically serious grounds as NS of a gene for Huntingon's? The answer is clearly "yes."

If we accept that some traits, possessing some degree of triviality, may undergo NS, then the medical seriousness claim is moot. Similarly, if some traits possessing some degree of seriousness can be accomplished using PS then the medical seriousness claim is also moot. A distinction between NS and PS is inadequate because we cannot be sure that only serious traits will require NS and only trivial ones will require PS. If the medical seriousness claim is moot, then for the remainder of this essay I will abandon the NS/PS distinction altogether and focus on the more relevant distinction: "serious" selection using PGD which I will refer to as genetic therapy (GT), and 'trivial' selection using PGD, which I will refer to as genetic enhancement (GE).

\section{Argument 2 - GT is the progression of medi- cine. GE is eugenics, and eugenics is wrong, as exemplified by the early 20 th century eugen- ics movement and Nazi Germany:}

It is true that very serious infringements of human rights have been committed in the name of eugenics. The eugenics movement of the early 2oth century saw massive sterilization of disabled persons in North America and Europe. Nazi Germany saw the murder of millions of 'inferior' citizens: the old, disabled, homosexuals, Jews and other minorities (Bostrom, 2005). Those who support GT and wish to differentiate between GT and GE often invoke the history of eugenics. They seek to make connections between GE and the eugenic practices of Nazi Germany: if GE belongs in the category of eugenics, and all eugenics is immoral, then GE is immoral. However, I disagree with the 'eugenics' claim and would assert that just because there are some applications of eugenics that are morally wrong, it doesn't mean that all applications, including GE, are morally wrong. I will try to differentiate GE from historical eugenics by pointing to a number of differences.

Arthur Caplan et al. (1999) delineate three distinguishing factors between 'Nazi-style' eugenics and GE. The first is coercion, which manifests itself in two immoral ways. In both the 2oth century and specifically, the Nazi eugenics practices, an overruling regime decided which phenotype was desirable and which was not. Those possessing an undesirable trait were sterilized or killed, both of which satisfied the eugenic principle of eliminating undesirable genes from the population (Caplan, McGee, \& Magnus, 1999). The first aspect of coercion is that all those under that regime were subjected to the same discrimination framework, which was not decided by the citizens but by the regime rulers. The second aspect of coercion was that the application of eugenics was a massive violation of a person's rights: the right to reproductive autonomy (in the case of sterilization) and the right to life (in the case of the murders). However, neither of these coercive phenomena need be present with the application of GE. Each set of parents will determine, on their own, if and how to discriminate between desirable and undesirable traits, and no person's rights will be infringed upon if embryos that don't possess desirable traits are killed (Glover, 1984). Instead, parents will simply be exercising their reproductive autonomy by choosing whatever qualities they wish to have in their offspring ${ }^{11}$ (Glover, 1984).

This is the second distinguishing factor of GE proposed by Caplan et al. (1999), which is the absence of 'subjective perfection' or a single ideal human form. This factor is similar to that of the first manifestation of coercion mentioned above, but it does not require a state to impose the 'subjective perfection' standard. Instead, it is simply the presence of such a homogenous standard. In Nazi Germany, for example, the homogenous standard for perfection was the 'Aryan race': Caucasian, blonde and blue eyed. GE however, would accommodate a myriad of different desirable traits if available worldwide. Some of these traits may be concentrated in some regions, as different cultures may traditionally value different characteristics, and there may be some prevailing tendencies in a given decade (Glover, 1984). These culture-related preferences, however, are already being selected for. Selection of preferred traits is not something owed only to PGD; conversely, peo- 
ple have long been choosing their mates based on biological or societal fitness characteristics. In this light, there is no comparison between Nazi-style eugenics, which aimed to homogenize the population to fit one subjective standard and GE to satisfy individual reproductive choice.

I recognize that with increased abilities to exercise reproductive choice come certain stipulations. Imagine a cult who desired to distinguish themselves by having children who all had a serious physical disability. GE for such traits would jeopardize the child's wellbeing and quality of life, and even subject him or her to discrimination (Glover, 1984). If children are protected from parental cruelty after they are born, should they not also have such protection before they yet exist? As with other policies currently in place to protect unborn children from parental abuse, such as restrictions on abusive first names, policy can and should be implemented to reflect an appropriate spectrum of GE outcomes in a given political system (Glover, 1984). It does not follow, however, that the need for regulation of a technology makes such a technology immoral. The crucial distinction between regulated GE and Nazi-style eugenics is, again, that coercion is absent in the former and central to the latter. As long as parents have the choice to opt in or opt out of PGD, human rights have not been infringed upon.

Another argument against GE focuses on the implications of enhancement in a more objective sense. It goes as follows: instead of the array of subjective traits produced by reproductive choice, selection for objective traits such as intelligence, athleticism, or memory will produce homogeny among the enhanced population, resulting in an 'overclass' (Caplan et al., 1999). GE will give advantages to those people who had rich enough parents to afford it. Inequality is immoral; therefore, GE is immoral. I agree that inequality is immoral, but such an argument falls prey to inconsistencies because children whose parents can afford many other things (good food, comfortable living, health care, private schools, university education) are also given unequal advantages over others. What is highlighted by this argument and its inconsistencies is that socioeconomic disparity is a major issue in societies; both in the developing and developed world (Caplan et al., 1999). This indeed results in inequality in children's futures, and I recognize that this is a major problem, but not one that can be blamed solely on PGD. If one is concerned with preserving equality, then one can start by providing all parents equal access to resources for their children. If GE becomes a reality, then equality could continue to be preserved by provid- ing it to all parents who desire it. As Caplan et al. (1999) describe, the bottom line is providing additional development and educational resources to make up for "differences in biological endowment" (Caplan et al., 1999, p. 337), whether genetically derived or not. This illustrates his third distinguishing factor: GE need not create inequality the way that Nazi-style eugenics did (Caplan et al., 1999). Rather, inequality should be looked at as a separate issue, one that will have negative consequences on society that are more far-reaching than in the context of GE (Caplan et al., 1999).

It seems that, upon closer inspection, that co-classification of Nazi-style eugenics and GE cannot rely on three immoral characteristics of historical eugenics: coercion, subjective definition of perfection, and inequality, as none of these three apply to GE. It also seems then, that historical examples of eugenics and eugenics derived from GE cannot be equated. This opens the possibility that, while eugenics such as the historical examples provided is definitely immoral, GE may not be. If other appeals are necessary to make a convincing argument that all eugenics is immoral, then GT advocates can no longer use the 'eugenics' claim to try and morally differentiate GT from GE. Thus, we continue the debate from the end of the second claim.

\section{Argument 3 - GE is wrong because it will per- petuate the immoral practice of sex selection:}

Perhaps the fiercest debate surrounding GE concerns the alleged danger that sex selection will perpetuate gender imbalance and subjugation of women. Those who oppose GE on the grounds that sex selection is immoral often point to Asian countries to exemplify the negative consequences that stem from reproductive power over gender (Savulescu, 1999; Ganatra, 2008). Late abortions and infanticide of female offspring are seen as cruel practices for they kill unjustly - solely based on sex (Ganatra, 2008). Abandonment, neglect or simply discarding the child at an orphanage are very much immoral and grave consequences of gender discrimination (Ganatra, 2008).

The issue I take with the 'sex selection' claim, based on the perpetuation of cruelty, is that it is not clear to me how cruelty itself would increase as a result of GE. Allowing PGD could actually decrease the frequency of such cruel practices. If parents could select the sex of a desired offspring before implantation, they would not have to resort to often unsafe abortions (Ganatra, 2008), infanticide or 
abandonment. Fewer rights would be infringed upon, as the embryo is a non-person in this debate, and fewer children would be destined to grow up in destitution as a result of their gender.

Of course, removing the more cruel practices associated with gender discrimination does not remove the discrimination itself; parents will still be subjectively choosing one gender over another. This type of discrimination, similar to discrimination based on race and disability, runs deep in many societies. Despite continuous global efforts to change people's mentalities on race and gender, we are debatably still close to the beginning of the long road to equality ("Women in the Workforce", 2009). If we are faced with the reality that, at least for the time being, such sexist mentalities prevail in the world, is it not our duty to minimize the casualties? ${ }^{12}$

Another issue I take with the sex selection claim is that it over-generalizes parents' intentions. Certainly, areas of the world such as China and India do show gender discrimination, but this does not necessarily apply everywhere (Savulescu, 1999). One study found that just over half of the parents who underwent sex selection during PGD in the US and the UK opted for girls (Savulescu, 1999). Another found that most Canadian parents actually chose girls (Savulescu, 1999). Perhaps most encouraging is that 90\% of American sex-selecting couples chose the gender that would balance the sex ratio between their offspring (Savulescu, 1999). It seems that such scenarios are unlikely to result in the human rights abuses discussed previously and that GE may not produce or exacerbate unhealthy parenting choices about sex.

In countries such as Canada, where an increasing percentage of the population is made up of South and East-Asian immigrants, there has been debate over whether cultural gender discrimination will threaten the balanced gender selection that has been recorded (Vogel, 2012). Statistics from highly concentrated South and East-Asian immigrant communities in various Canadian cities show a significant imbalance in the offspring gender ratio - and the suggested mode of sex selection is abortion (Vogel, 2012). Does this mean that, due to our large influx of immigrants, that PGD will be increasingly exploited for sex selection, and is thus to be prevented from being applied altogether? First of all, PGD would remove the female feticide practices and replace them with safer, earlier termination of embryos (see earlier discussion on casualties). Second of all, such an assumption discredits the education and open-mindedness of the second and third generations - the children of firstgeneration immigrants. These children will enter the Canadian school system, many will pursue college or university degrees, and will be exposed to direct and indirect education about gender roles, gender equality, human rights, and social structure as it is in Canada. To assume that all these children will preserve the sexist values of their parents is insulting, and untrue. Even if a boy is still desired, better socioeconomic conditions combined with PGD could mean that parents can select a boy, and be able to afford having another child - boy or girl - as well.

One Canadian case highlights an interesting biological limitation to sex selection using PGD. One Canadian mother, who underwent IVF with the hopes of producing a fifthgeneration namesake for her husband, was told that all her healthy embryos were female (Abraham, 2012). This can be related back to the concern about East-Asian sex selection: instead of blindly trying to produce a boy and disposing of an undesirable girl in a number of very cruel ways, parents could be told their options before undergoing implantation and gestation. If they know that their only chance of having a healthy child means that it will be female, then they can decide against conception altogether or make the decision to keep a female embryo. I believe that, psychologically, the act of consciously choosing a girl may foster a more healthy perspective of the coming baby, and result in better parenting and care for girls.

In light of these arguments, it seems that the only thing accomplished by sex selection is giving parents more freedom to choose which children they will have at an earlier stage. At the very least, GE would make it possible to eliminate the cruel practices associated with sex selection today and allow parents a safe and humane way to opt out of bringing a pregnancy to term if their healthy embryos do not include a given sex. As seen with the American statistic stated above, it is possible that in some parts of the world, sex selection may actually work towards equalizing the gender ratio (Abraham, 2012). It is unclear to me, therefore, how GE would necessitate any cruelty or rights abuse practices related to sex selection, nor how it would exacerbate sex selection where it already exists, nor again how it would produce gender imbalance.

\section{Argument 4-GE is wrong. Our intuition tells us so, because human enhancement is repug- nant to us:}


There are certainly many cases in which humans use some innate feeling, or intuition, to guide their moral thoughts and practices. There are certain things that most people will inherently feel good about and other things that will induce the so-called 'yuck factor' (Bostrom, 2005). This intuitive moral repugnance is often activated in reaction to concepts such as rape, incest, pedophilia or torture (Bostrom, 2005). Bioconservative philosophers such as Leon Kass often invoke this moral repugnance as proof that GE is immoral (Roache \& Clark, 2009). Thus, we find ourselves facing another claim against GE. This one seeks to identify negative intuitions as a morally relevant quality of human enhancement, in order to distinguish GE from GT.

In order to build an objection to the 'intuition' claim, I will make the following arguments: 1) intuitions about GE are inconsistent, 2) the bioconservative definition of the immoral element of repugnance is weak, and 3) in general, intuitions may be poor moral compasses.

If our moral repugnance of human enhancement is to carry moral weight, it should be trustworthy across all forms of $\mathrm{GE}$; that is, all examples of congenital alteration of human phenotypes. Many forms of accepted human enhancement, such as those driven by social mating behaviours, are genetic in nature (Glover, 1985). Consider the forces that influence some people to have many offspring and others to have none (such as policies or culture) and those that drive sexual selection (who is an attractive mate and who is not). Both forces have an impact on whose genes get passed on and in which combination. In most countries, rich people can generally afford to have more children, and career-driven women often have fewer children ("Women in the Workforce", 2009), whether by choice or necessity. These practices do not elicit moral repugnance, yet they accomplish genetic enhancement. No one tries to prevent two smart people from choosing each other as mates, nor two blue-eyed people, nor two professional basketball players. Yet such selection can no doubt have the same outcome as enhancement using PGD; increasing the probability of achieving a particular trait (nature can only do so much by way of ensuring a given phenotype). To conclude, if one can engage in many forms of non-genetic and genetic human enhancement without an onslaught of negative moral intuitions then the immorality of GE using PGD based on intuition loses its logic. If our intuitions speak out against GE, then why don't they speak out against all over forms of genetic enhancement?
The inconsistencies that become obvious when the intuition claim is applied to GE are compounded by the weakness of the definition of moral repugnance itself. This is my second argument against the intuition claim. When asked to describe in analytical terms the 'wrongness' - that element that our intuition identifies and repulses - philosophers such as Kass counter that most of us cannot give "argument fully adequate to the horror" (Roache \& Clark, 2009, p. 5) of acts like rape, incest, of pedophilia, yet it doesn't follow that our repugnance can therefore be dismissed as incorrect (Roache \& Clark, 2009).

Martha Nussbaum critiques Kass' repugnance argument by pointing out that every example he gives involves repugnance but also harm to others. Rape and pedophilia violates one's right to consent, to sexual autonomy and to live violence-free, and incest is often both rape and pedophilia (Nussbaum, 2004). What we are really feeling in scenarios such as rape or pedophilia is the revulsion at the major breach of rights (Nussbaum, 2004).

What Kass fails to do is produce an example of something that 1) elicits repugnance, 2) is immoral, but 3) that does not violate someone's rights (Nussbaum, 2004). If he could do that, he could prove that repugnance can work as a moral compass independently from rights-based analyses. Instead, what Kass is doing is conflating repugnance in general with rights-based intuition.

To exemplify this, I offer the following two scenarios. The first considers incest, for example between a father and a daughter. Kass would say that our moral repugnance expresses the wisdom that incest is immoral. Nussbaum would say that incest is immoral because it is a violation of the daughter's rights. Now, imagine removing the rights violations by replacing the father-daughter couple with an adult, consenting brother-sister couple. Do we feel repulsed now? If yes, our repulsion cannot be due to a rightsbased intuition (Nussbaum, 2004). It would need to be due to some general 'yuck factor', or as Nussbaum calls it, disgust (Nussbaum, 2004). For example, it could be because we are personally disgusted at the thought of being intimate with our own sibling. Alternately, many of us may feel significantly less repugnance to cases of brother-sister incest: as Nussbaum points out, consensual incest was rampant among historical royal families, yet we continue to celebrate them and cherish their legacies (Nussbaum, 2004). To conclude, in the case of incest, once rights violations are removed from a scenario and rights-based intuitions disappear, general repugnance (disgust) could still 
exist, but for reasons other than immorality (Nussbaum, 2004).

My second example illustrates how general repugnance can be applied in morally irrelevant ways, thus distinguishing it even more from rights-based intuitions. Nussbaum asks us to consider our repugnance to things like feces, semen, or nasal mucous (Nussbaum, 2004). Does our repugnance signify that these things are violating someone's rights? More importantly, consider some people's repugnance to the "handicapped, the deformed, or the morbidly obese" (Nussbaum, 2004). Is their existence immoral? Does it violate anyone's rights? I believe that Nussbaum exposes a fatal implication of Kass' argument. Either repugnance is a completely useless moral compass and can at most supplement our rights-based intuitions, or our repugnance toward the handicapped is well-founded and they should receive moral and legal judgment similar to that of rapists and pedophiles.

To formulate my third opposition against the intuition claim, I echo Peter Singer, another opponent of Kass' repugnance argument, who proposes that reasoning should always win over intuition. Singer questions the validity of our intuitions in general on the basis that they, being inborn psychological reactions based on neurological pathways, are products of the evolution of our central nervous system (Roache \& Clark, 2009). Selective pressures on our ancestors favoured repugnance to something like incest, says Singer, because the small social groups we lived in made inbreeding (and the resulting decrease in evolutionary fitness) a high probability unless it was consciously avoided (Roache \& Clark, 2009). Roache and Clark (2009) build on Singer's postulate by suggesting that intuitions may have some value, but not when they are about something with which we have no experience or historical groundwork. Why are intuitions about novel circumstances untrustworthy? Firstly, we may be predisposed to doubt the morality of all new scientific advancements (Bostrom, 2005). Many of these predisposed moral doubts, as history shows us, were eventually dropped. As biochemist J.B.S. Haldane observed,

"The chemical or physical inventor is always a Prometheus. There is no great invention, from fire to flying, which has not been hailed as an insult to some god. But if every physical and chemical invention is a blasphemy, every biological invention is a perversion. There is hardly one which, of first being brought to the notice of an observer from any nation which has not previously heard of their existence, would not appear to him as indecent and unnatural" (Haldane, 1923).

In addition, it is certainly true that our early moral intuitions about the morality of issues pertaining to our social interactions or perceptions have proven to be wrong. Slavery, gender equality, gay marriage and interracial marriage were also, at one time, considered immoral (Nussbaum, 2004) - and unfortunately still are in some areas of the world. In light of these two arguments, it seems that GE may fit both descriptions: because it is a novel technology we may have a (possibly incorrect) predisposition to judge it, and because it pertains to human society and our perception of humanity our intuitions about its morality reflect a poor track record and are likely to be unsustainable. If all this is added to the proof that intuitions on this particular subject are fraught with inconsistencies (as shown earlier) and the reliance on repugnance a moral compass is largely useless, it seems that the intuition claim is a poor candidate to morally distinguish GE from GT.

\section{Considerations of Human Virtue: An impasse, or a cautious way forward?}

Negative selection is accepted on the basis of duty to prevent pain and suffering, and due to the moral rightness of practices, even those that are genetic, that restore baseline human functioning. Negative selection has subsequently been proven to be indistinguishable from positive selection on the basis that there are many serious traits that can be positively selected, and many trivial traits that can be negatively selected. Moving forward from the positivenegative debate, we can call the selection of all 'serious' traits GT, and the selection of all 'trivial' traits GE. The distinction between therapy and enhancement, however, is also difficult to make in any meaningful way. As we saw, there were a number of weak claims, that GE is either a purely selfish parental wish, a form of eugenics comparable to the Nazi regime, or an evil process that will perpetuate immoral sex selection, which do not hold true universally. In addition, we cannot rely on our intuitive repugnance to GE to guide debate of its morality.

Where does that leave us? Is bioconservatism a worthless philosophy when applied to GE by PGD? Are we to adopt the opposite view, transhumanism, and enforce all forms of GE using PGD? Before defending my own conclusions to this impasse, I would like to present one final argument made by bioconservatives. I believe this argument to be the 
most important in influencing my conclusion because it shifts the perspective of the debate. Instead of assessing the objective morality of GE using PGD, it addresses the more subjective consideration that must be made of the moral agents who will be applying it. It also addresses the pervasive theme of regulation, and demonstrates how the need for regulation reflects the questionable morality of the agents, and not of the technology itself.

Much of the bioconservative philosophy, in addition to its concern with intuitive repugnance, attacks GE on the basis that it threatens a certain 'humanness', or human dignity (Bostrom \& Savulescu, 2008; Vallor, 2009). Although the debate about human dignity is an interesting one, I have chosen not to include it in this essay. I have found that debates about human enhancement largely look beyond PGD, as germ line genetic alterations and human cloning become ever more tangible. The idea proposed by the bioconservatives that does influence PGD specifically, and which I think is relevant to the current debate, concerns not the process of GE itself, but the virtue of the moral agents who will be responsible for executing the enhancement. As Shannon Vallor describes, the bioconservative position rests in large part on a "deep uncertainty about the intellectual ability and moral will of today's humans to transform themselves wisely and well... do we today possess the extraordinary ambition, moral imagination and prudential insight needed to wisely and effectively implement such a radical program?" (Vallor, 2009, p. 41). The pessimistic answer, she says, is that our actions have proven that we are lacking the virtue to use technologies such as PGD in a moral way, regardless of whether it is moral or not (Vallor, 2009). We need look no further than the genocide, rape, sex slavery or terrorism that go on today to feel compelled to deeply distrust at least some people with the power of selecting embryos for enhancement reasons (Roache \& Clarke, 2009). What bodes worse for human virtue is our apparent inability to learn from our mistakes. A major resistance to GE using PGD lies, as we have seen, in our deep desire to avoid anything related to Nazi Germany. Transhumanist philosopher Nick Bostrom describes it as a defense mechanism set against repeating the history of genocide (Bostrom, 2005). The question is, did we assimilate anything at all from our experiences if we stood by and allowed history to repeat itself less than fifty years later in Rwanda? (Bostrom, 2005).

Such doubt about human virtue leads to apprehensive thoughts about the employment of PGD for GE. As Vallor recognizes, however, a resolution may not be available, for current doubt can neither be "rejected on the grounds of cynicism alone, as transhumanists have done" nor "confirmed by mere intuition" (2009, p. 41), as many bioconservatives would prefer. This, says Vallor, leaves the virtue debate at an impasse until either hypothesis can be proven (2009).

So far, this dissertation has been progressing steadily in the defense of the moral soundness of GE using PGD. Vallor's impasse, however, is unsatisfactory. Although unrelated to the morality of GE itself, the human virtue debate is intimately tied to this discussion due to the fact that PGD relies on moral agents for its execution. An impasse is of no use to applied ethics, which seek to guide practices that are already happening. Wise decisions about policy need to be made now, and cannot afford to risk the consequences of waiting until the impasse is resolved. The last question I must ask is this: is there some way to resolve the impasse without concluding that GE is a lost cause, that its morality has been undone by its moral agents?

Bioliberalist Jonathan Glover proposes an attractive formula for implementation of GE. Firstly, it acknowledges the distinction between the morality of GE itself and of its moral agents. Secondly, it gives some merit to our intuitions about PGD while also accommodating their transient nature. Thirdly and most importantly, it provides a practical solution to the impasse.

Glover supports GE on the basis that it is morally indistinguishable from GT and on the basis that it will benefit humanity (Glover, 1984). He also echoes the concern about moral agents and their threat to the applicability of an otherwise moral enhancement: "the trouble lies not with techniques for enhancement...but with a society's commitment to equality" (Baldwin, 2006, p. 673). As much as our intuitions can be problematic, they should not be completely discarded in this matter. Where does that leave us with regards to implementation of GE? Perhaps the dogma "optimism in principle, caution in practice" (Baldwin, 2006, p. 673) is the best way to summarize the two mutually crucial components of GE implementations. As with other new or powerful technologies such as virus engineering, geo-mapping or social media, I believe that regulation of GE is not only appropriate, but it is necessary if we are to benefit from such powerful (and otherwise morally sound) technologies while restricting their exploitation by those of poor virtue. 
I recognize the disadvantage of implementing regulations: one has replaced the problem of power given to a morally suspect humanity with power given to a morally suspect few. Who will enforce the regulations? More importantly, who will decide which to enforce? These questions could be answered in the cynical perspective of the virtue debate. We could say that it is doubtful if any body of power will prove to have moral virtue, and that the powerful few will exploit GE in immoral ways, and that all potential for GE to benefit humanity will be lost.

One of Glover's central points in his analysis of GE implementation is that the demand for caution does not infer that outright ban on enhancement is the answer (Glover, 2006). As we have seen throughout this discussion, acknowledging regulation as a necessary concession does not preclude the possibility that PGD is both moral and beneficial to humanity. Should we destroy all the viral vectors we are developing for the delivery of drugs because centralized bodies restrict its use for biowarfare? Should we destroy all communication satellites because regulation of their application is necessary to protect privacy? Should we destroy all forms of social media because a powerful few can restrict its use for pornography, pedophilia or hate crimes?

If the risk of undesirable outcomes were enough to stop a technology from going forward, we would see little innovation, as most new technologies come with risks (Glover, 2006). Recall that even libertarians such as Nozick are willing to cede some autonomy in exchange for a rightsbased regulation system (Glover, 1984). As there are appropriate, rights-based regulations in place for satellite or internet use, there must be some appropriate version of regulation available for PGD. I propose that regulations should be considered, but only in 2 ways: 1 ) as an equalizing force, and 2) to prevent rights abuse. In the first case, regulation would not favour one outcome or another but may flip flop in its trajectory depending on the ratio between two outcomes, the perfect example being the sex ratio equalizing regulation proposed by Nozick (Glover, 1984). In the second case, our decisions could mimic existing rights-based legislature for other technologies. In addition, it could include Glover's suggestion that centralized bodies exist only to enforce regulations, and to act as veto in otherwise public decisions about the legislature (Glover, 1984). This democratic implementation of PGD regulations would both reflect the public's current pessimistic intuitions about human virtue and provide flexibility for gradual changes in our intuitions (Glover, 1984).
Luckily, in the case of PGD, there are several biological laws that will regulate the progression of PGD in a cautious and gradual way. To start, allowing parents to select embryos with the intent of enhancing their children will not produce unbridled enhancement of children born through PGD, nor will it produce an extreme phenotypical enhancement in one generation. There are two forces behind this. First, PGD does not create genetic material de novo, and is thus limited by the available genetic material. A woman has a limited number of eggs. As genes are added to the list of desired phenotypes, the probability that any one embryo will contain them all decreases exponentially. Second, an embryo that was selected because it has a gene linked to increased height will not produce a 7 -foot person. Mendelian traits, phenotypes that are linked to only one gene, are rare (Abraham, 2012). The majority of our traits are the products of several genes interacting with each other and with the environment in complex ways, and so the effect that GE using PGD will have on the immediate progeny will likely be limited to Mendelian genotypes (Abraham, 2012).

In summary, a combination of Glover's principles and biological limitations provides a very practical way forward from the transhumanist-bioconservative impasse. GE using PGD is morally indistinguishable from GT using PGD. Limiting its use is illogical, especially while we simultaneously use GT for the benefit of humanity. GE implementation need not produce inequality, whether socioeconomic, gender-based or rights-based. Despite the absence of rights -abuse, change in human intuitions may come slowly, but I believe that taking a libertarian but cautious approach in the application of GE using PGD would facilitate that adjustment process and provide us with concrete experiences on which to critically evaluate our intuitions. Based on historical examples of novel ideas about technology and human social structures, a shift in our moral compass and an acceptance of its benefits seems entirely possible if we employ appropriate regulation and implement GE gradually.

\section{Notes}

[1] Once fertilized embryos have undergone early cell division to form a morula (a ball of genetically identical cells), some cells can be removed without compromising the embryo's development. The DNA from these cells can be screened to identify which type of allele exists at a certain gene locus. In other words, laboratory tests decode the 
DNA at the known location of a gene, and in doing so can sometimes determine if it is a gene that will cause disease or disorder.

[2] Genes for diseases such as Huntington's Tay-Sachs and cystic fibrosis are some such undesirable alleles negatively selected using PGD (Purdy, 1996; Abraham, 2012).

[3] Sex selection is a common example of PS done today (Abraham, 2012)

[4] Such anti-abortionists being those who believe that an embryo is significantly less of a person than a fetus (Purdy 1996). PGD to execute NS, which terminates life at the embryo stage, could thus be morally permissible, since a nonperson does not have a right to life (Tooley, 1972).

[5] According to Thompson, embryos - even if they are persons - have no right to impose upon the autonomy of the parents (especially the mother) in deciding if and when to undergo a pregnancy (Thompson, 1971).

[6] The utilitarian view always aims to take overall benefit or happiness (utility) into consideration when calculating the morality of a given action (Singer, 1974).

[7] This philosophy that holds the view that it is permissible and even desirable to push the limits of humanity using technologies. (Roache and Clarke, 2009).

[8] Parents are currently using Canadian IVF clinics to eliminate several disease genes using PGD (Abraham 2012). The number of fertile parents seeking PGD is also increasing, although its most common use is still NS for unhealthy embryos in women with low fertility (Abraham 2012). Perhaps the most striking trend is the increasing desire of PS and the willingness of those parents who cannot obtain screening for the traits they want in Canada to go to Mexico, where IVF clinics will even allow sex selection during PGD (Abraham, 2012).

[9] The Supreme Court of Canada prohibits PS of sex, and most Canadian PGD practitioners strictly refuse any form of PS (Abraham 2012). Dr. Nisker, a pioneer in PGD and the founder of the second largest Canadian IVF clinic, shut down PGD altogether when he realized that the majority of his patients were requesting PS (Abraham, 2012).

[10] In IVF, several embryos are implanted to increase the probability of success of the pregnancy, The outcome is that several health embryos are discarded during every OVF treatment. An anti-abortionist philosophy would see this as an act of killing unjustly - making IVF an immoral practice.

[11] An interesting implication of allowing GE as a function of parent's reproductive anatomy is that some parents may consider selecting for a disability such as deafness, especially if they possess the disability themselves (Chadwick \& Levitt, 1998). Is such a decision morally equal to other forms of GE? In the framework of this argument, one would have to agree that it is. Moreover, children with elected disabilities such as deafness serve as a further distinctive quality between GE and Nazi-style eugenics scenarios, for in the first they are valued as members of society and in the second they are killed.

[12] For further ethical dilemmas surrounding perpetuation of immoral practices versus minimizing their casualties, see MSF paper by Sheather and Shah (2011).

\section{References}

Abraham, C. (2009, January 7). Unnatural selection: Is evolving reproductive technology ushering in a new age of eugenics? The Globe and Mail. Retrieved

from www.theglobeandmail.com

Baldwin, T. (2006). Book review: The chosen child. European Molecular Biology Organization Reports, 7(7), 673. doi: 10.1038/sj.embor.7400744

Bostrom, N. (2005). A history of transhumanist thought. Journal of Evolution and Technology, 14(1), 1-30. Retrieved from http://jetpress.org/volume14/ bostrom.html

Bostrom, N., \& Savulescu, J. (2008). Introduction. In N. Bostrom \& J. Savulescu (Eds.), Human Enhancement (pp. 1-24). Oxford University, Oxford: Oxford University Press.

Caplan, A. L., McGee, G., \& Magnus D. (1999). What is immoral about eugenics? British Medical Journal, 319, 12841285. Retrieved from http://dx.doi.org/10.1136/

bmj.319.7220.1284

Chadwick, R., \& Levitt, M. (1998). Genetic technology: A threat to deafness. Medicine, Healthcare and Philosophy, 1, 209-215. Retrieved from http://link.springer.com/ article/10.1023\%2FA\%3A1009960924838

Crowe, K. and Dakin, P. (2012, January 16). Selective abortions prompt call for ultrasound rules. Canadian Broadcasting Corporation News. Retrieved from www.cbc.ca 
Ganatra, B. (2008). Maintaining access to safe abortion and reducing sex ratio imbalances in Asia. Reproductive Health Matters, 16(31), 90-98. doi: 10.1016/So968-8080 (o8)31394-9

Glover, J. (1984). Questions about some uses of genetic engineering. In T. Honderich (Ed.), What sort of people should there be? (pp. 25-52). Harmondsworth, UK: Penguin Books.

Glover, J. (2006). Choosing children: Genes, disability, and design. Oxford University, Oxford: Oxford University Press.

Haldane, J. B. S. (1923). Deadalus or science and the future. Cambridge, UK: E. P. Dutton and Company.

Nussbaum, M. (2004). Hiding from humanity: Disgust, shame, and the law. Princeton University, NJ: Princeton University Press.

Purdy, L. M. (1996). Genetics and reproductive risk: Can having children be immoral? Chapter 1 from Reproducing Persons: Issues in Feminist Bioethics. Ithaca, NY: Cornell University Press.

Roache, R., \& Clark, S. (2009). Bioconservatism, bioliberalism, and the wisdom of reflecting on repugnance. Monash Bioethics Review, 28(1), 1-21. Retrieved from http://journals.publishing.monash.edu/ojs/ index.php/mber/article/view/571

Savulescu, J. (1999). Sex selection: The case for. Medical Journal of Australia, 171, 402- 405. Retrieved from https://www.mja.com.au/journal/1999/171/7/sexselection-case

Sheather, J., \& Shah, T. (2011). Ethical dilemmas in medical humanitarian practice: cases for reflection for Medecins Sans Frontieres. Journal of Medical Ethics, 37, 162-165. doi: 10.1136/jme.2010.038448

Singer, P. (1974). All animals are Equal. Philosophical Exchange 1(5), pp. 103-116. Retrieved from https:// iseethics.files.wordpress.com/2013/02/singer-peter-allanimals-are-equal-original.pdf

Thompson, J. J. (1971). A defense of abortion. Philosophy and Public Affairs, 1(1), 47- 66. Retrieved from http:// www.jstor.org/stable/2265091

Tooley, M. (1972). Abortion and infanticide. Philosophy and Public Affairs, 2(1), 37-65. Retrieved from http:// www.jstor.org/stable/2264919

Vallor, S. (2009). Enhancement Technologies and human dignity: on the virtue of transformation. Proceedings of The Society for Philosophy and Technology: Converging Technologies, Changing Societies (pp. 40-41). Twente. Proceedings available at http://www.utwente.nl/gw/wijsb/ archive/Archive\%20activities/spt2009/programme/ proceedings.pdf

Vogel, L. (2012). Sex selection migrates to Canada. Canadian Medical Association Journal, 148(3), 163164. doi: 10.1503/cmaj.109-4091

Women in the workforce: female power (2009, December 30). 2009.The Economist. Retrieved from http:// www.economist.com/node/15174418 